\title{
Modeling Growth and Development of Celosia and Impatiens in Response to Temperature and Photosynthetic Daily Light Integral
}

\author{
Lee Ann Pramuk ${ }^{1}$ and Erik S. Runkle ${ }^{2}$ \\ Department of Horticulture, Michigan State University, East Lansing, MI 48824
}

\begin{abstract}
AdDitional INDEX wORDs. bedding plants, Celosia argentea var. plumosa, flowering, Impatiens wallerana, light intensity, scheduling

Aвstract. Commercial greenhouse growers often produce bedding plants from midwinter to early summer, and thus crops are grown under a wide range of environmental conditions. Despite bedding plants' high economic value, the interactions of temperature and photosynthetic daily light integral (DLI) on growth and flowering have not been determined for many bedding plants. We grew celosia (Celosia argentea $\mathrm{L}$. var. plumosa $\mathrm{L}$.) and seed impatiens (Impatiens wallerana Hook.f.) in glass greenhouses in a range of temperature $\left(15\right.$ to $\left.27^{\circ} \mathrm{C}\right)$ and DLI $\left(8\right.$ to $\left.26 \mathrm{~mol}^{-2} \cdot \mathrm{m}^{-2} \cdot \mathrm{d}^{-1}\right) \mathrm{conditions}^{-}$ to quantify effects on growth and flowering. Growth (e.g., plant dry mass at flowering) and flowering characteristics (e.g., time to flowering and flower bud number) were modeled in response to the average daily temperature and DLI by using multiple regression analysis. Rate of progress to flowering (1/days to flower) of celosia increased as temperature increased up to $\approx 25{ }^{\circ} \mathrm{C}$ and as the average DLI increased to $15 \cdot \mathrm{mol} \cdot \mathrm{m}^{-2} \cdot \mathrm{d}^{-1}$. Impatiens grown under a DLI $<15$ $\mathrm{mol} \cdot \mathrm{m}^{-2} \cdot \mathrm{d}^{-1}$ flowered progressively earlier as temperature increased from 14 to $28{ }^{\circ} \mathrm{C}$, whereas temperature had little effect on flowering time when plants were grown under the highest DLI treatments. Number of flowers and flower buds at first flowering increased in both species as temperature decreased or DLI increased. Shoot dry mass at first flowering followed a similar trend, except celosia dry mass decreased as temperature decreased. The models developed to predict flowering time and plant quality could be used by commercial growers to determine the impacts of changing growing temperature, growing plants at different times of the year, and providing supplemental lighting.
\end{abstract}

Bedding and garden plants compose the largest segment (48\%) of floriculture crop production in the United States, and in 2003, the reported wholesale value was $\$ 2.42$ billion (USDA, 2004). The majority of bedding plants are grown in greenhouses from January through May for sales in late spring and early summer. Many greenhouse growers produce two or three bedding plant crops during this period, so the environmental conditions for the first crop are usually different than for a second and third crop.

The outdoor temperature is considerably lower in early spring than in late spring, so most growers in northern climates (e.g., above lat. $40^{\circ} \mathrm{N}$ ) provide heating to maintain a desired greenhouse temperature. The cost to heat a greenhouse has increased in the past decade because the cost of fuel (e.g., natural gas and heating oil) has increased. For example, the average price of natural gas sold to commercial growers in the United States was \$23.03 per $100 \mathrm{~m}^{3}$ in 1990 (adjusted for inflation), and in Sept. 2001, the average price was $\$ 31.75$ per $100 \mathrm{~m}^{3}$ (Energy Information Administration, 1999, 2001). In response to the energy cost increase, some growers lowered their nighttime temperature set point to reduce monthly energy consumption. However, the effects of temperature on crop growth (plant quality) and development (time to flower) have not been quantified for many common bedding plant species.

In addition to temperature, DLI in the northern hemisphere increases from January to May, but the magnitude depends on location. For example, in January the average outdoor DLI is

Received for publication 28 Feb. 2005. Accepted for publication 7 May 2005. We gratefully acknowledge funding from growers providing support for Michigan State Univ. floriculture research and the support from the Michigan Agricultural Experiment Station.

${ }^{1}$ Former graduate student.

${ }^{2}$ Assistant Professor of Horticulture and Extension Specialist, to whom reprint requests should be addressed (Email: runkleer@msu.edu).
$<15 \mathrm{~mol} \cdot \mathrm{m}^{-2} \cdot \mathrm{d}^{-1}$ in Michigan and $>25 \mathrm{~mol} \cdot \mathrm{m}^{-2} \cdot \mathrm{d}^{-1}$ in Florida; in May the DLI can exceed $50 \mathrm{~mol} \cdot \mathrm{m}^{-2} \cdot \mathrm{d}^{-1}$ in Michigan and Florida (Korczynski et al., 2002). The amount of light available to plants inside a greenhouse can be $50 \%$ or less of that outdoors because of shading from the structure, glazing materials, and other obstructions (Hanan, 1998). Therefore, bedding plants are grown under an average DLI ranging from $<8$ to $>25 \mathrm{~mol} \cdot \mathrm{m}^{-2} \cdot \mathrm{d}^{-1}$. The effects of DLI on plant growth and development, and especially the interaction of DLI with temperature, have not been described for many floriculture crops.

We grew two common bedding plants, celosia and seed impatiens, under a range of temperature $\left(15\right.$ to $\left.27^{\circ} \mathrm{C}\right)$ and DLI (5 to $\left.26 \mathrm{~mol} \cdot \mathrm{m}^{-2} \cdot \mathrm{d}^{-1}\right)$ conditions to quantify effects on growth and flowering. The range of temperature and DLI treatments represent typical conditions for bedding plant growers in middle latitudes (e.g., 20 to $45^{\circ} \mathrm{N}$ ). Our objectives were to determine the relative contributions of temperature and DLI to growth and development so that greenhouse growers can improve prediction of flowering and understand the consequences of growing crops under different temperature and DLI conditions. From these data, the temperature at which developmental rate is zero (the base temperature) can be estimated. Impatiens is one of the most valuable bedding crops grown: in 2003, the reported wholesale value sold in the United States was \$154 million (USDA, 2004). Although celosia is another common bedding plant produced, sales are not reported by the USDA but is estimated to be $\$ 40$ million.

\section{Materials and Methods}

Seedling Plug Culture. Seeds of celosia 'Gloria Mix' and impatiens 'Accent Red' were sown in 288-cell (5-mL) plug trays on 25 Jan. 2002 and 2 Apr. 2002 at a wholesale plug producer (Raker's Acres, Litchfield, Mich.). The germinated seeds were 
received at Michigan State University on 29 Jan. 2002 and 8 Apr. 2002 so that the DLI during the early stages of development could be controlled. The 288-cell trays were placed in a growth chamber set at $23{ }^{\circ} \mathrm{C}$ under $150 \mu \mathrm{mol} \cdot \mathrm{m}^{-2} \cdot \mathrm{s}^{-1}$ provided by cool-white fluorescent (VHOF96T12; Philips, Bloomfield, N.J.) and incandescent lamps with a 16-h photoperiod. A vapor pressure deficit of $0.7 \mathrm{kPa}$ was maintained. Plugs were top irrigated with well water [containing $\left(\mathrm{mg} \cdot \mathrm{L}^{-1}\right) 95 \mathrm{Ca}, 34 \mathrm{Mg}$, and 29 S] supplemented with a water-soluble fertilizer to provide the following $\left(\mathrm{mg} \cdot \mathrm{L}^{-1}\right): 40 \mathrm{~N}, 4 \mathrm{P}, 40 \mathrm{~K}, 5 \mathrm{Ca}, 0.3 \mathrm{Fe}, 0.03 \mathrm{~B}$, $0.03 \mathrm{Mo}, 0.2 \mathrm{Mn}, 0.2 \mathrm{Zn}$, and 0.2 Cu (MSU Special; Greencare Fertilizers, Chicago). Water was acidified with $\mathrm{H}_{2} \mathrm{SO}_{4}$ to a titratable alkalinity of $\mathrm{CaCO}_{3}$ at $140 \mathrm{mg} \cdot \mathrm{L}^{-1}$. Seedlings were grown until deemed ready for transplant, which was 23 and $26 \mathrm{~d}$ from sowing for impatiens and celosia, respectively.

Greenhouse temperature AND DLI Treatments. For each species and experiment, 150 seedlings were removed from the growth chamber and transplanted into $10-\mathrm{cm}$-diameter pots (470$\mathrm{mL}$ ) containing $70 \%$ peat moss, $21 \%$ perlite, and $9 \%$ vermiculite (Suremix, Michigan Grower Products, Galesburg, Mich.). Thirty plants of each species were placed into five similar glass greenhouse compartments set at constant air temperatures of $14,17,20,23$, and $26^{\circ} \mathrm{C}$. Vapor pressure deficit was maintained between 0.7 and $1.0 \mathrm{kPa}$ by steam injection. In the center of each greenhouse section, air temperature was measured by a type $\mathrm{E}$ thermocouple (TT-E-40; Omega Engineering, Stamford, Conn.) placed in an aspirated tube. Thermocouples were connected to a CR10 data logger (Campbell Scientific, Logan, Utah), and data were recorded every $10 \mathrm{~s}$. The actual average air temperatures during the experiments were $15.1,17.4,20.3,24.2$, and $26.7^{\circ} \mathrm{C}$ (first experiment) and $16.8,17.6,20.7,25.5$, and $27.1^{\circ} \mathrm{C}$ (second experiment).

Three DLI treatments were provided to plants at each of the five temperature treatments, with 10 plants under each DLI and temperature combination ( 15 treatments total). The DLI treatments were delivered using a combination of shadecloth and different light intensities from high-pressure sodium (HPS) lamps, which delivered a 16-h photoperiod (from 0600 to $2200 \mathrm{HR}$ ). A low DLI was provided using ambient light with $50 \%$ shade cloth (OLS 50; Ludvig Svensson, Charlotte, N.C.) and supplemental HPS lighting that delivered a PPF of $35 \mu \mathrm{mol} \cdot \mathrm{m}^{-2} \cdot \mathrm{s}^{-1}$ at plant level. Plants under the moderate and high DLI treatments were grown under ambient light without shadecloth and with supplemental HPS lighting that provided a PPF of 75 or $170 \mu \mathrm{mol} \cdot \mathrm{m}^{-2} \cdot \mathrm{s}^{-1}$, respectively. Line quantum sensors containing 10 photodiodes (Apogee Instruments, Logan, Utah) were placed directly above plants under the three lighting treatments in three greenhouse compartments (nine sensors total) to measure the PPF. Sensors were connected to the CR10 data logger and data were recorded every $10 \mathrm{~s}$. The actual calculated average DLIs under the low, moderate, and high DLI treatments were 7.6, 15.8, and 21.6 $\mathrm{mol} \cdot \mathrm{m}^{-2} \cdot \mathrm{d}^{-1}$ during the first experiment and $11.4,21.2$, and 25.6 $\mathrm{mol} \cdot \mathrm{m}^{-2} \cdot \mathrm{d}^{-1}$ during the second experiment, respectively.

Plant Culture ANd data Collection. Plants were top irrigated as necessary with acidified well water (as described above) supplemented with a water-soluble fertilizer containing $\left(\mathrm{mg} \cdot \mathrm{L}^{-1}\right)$ : $125 \mathrm{~N}, 13 \mathrm{P}, 125 \mathrm{~K}, 15 \mathrm{Ca}, 1 \mathrm{Fe}, 0.1 \mathrm{~B}, 0.1 \mathrm{Mo}, 0.5 \mathrm{Mn}, 0.5 \mathrm{Zn}$, and $0.5 \mathrm{Cu}$ (MSU Special). Date of flowering was recorded, and at flowering, the following were measured: plant height from soil level, number of nodes on the primary shoot, total shoot dry mass, number of flowers and flower buds (flower number), and diameter of the first open flower. Impatiens was considered in flower when all petals were fully reflexed; celosia was considered in flower when the primary inflorescence reached $4 \mathrm{~cm}$ in length.

DATA ANALYSIS. Data were analyzed using the calculated average daily air temperature and DLI for each plant from transplant to the date of flowering. Flowering data were converted to rates by taking the reciprocal of days to flowering. Multiple regression analysis was performed using SAS (SAS Institute, Cary, N.C.) response surface regression (RSREG procedure) to determine the effect of DLI in combination with air temperature. Similar studies with temperature and DLI have used similar forms of analysis (Adams et al., 1997; Carew et al., 2003). If the contribution of individual terms to the model was not significant $(P>0.05)$, the terms were removed, and regression (REG procedure) was used to determine the model coefficients. Equations were then used to generate predictive models. Approximately 300 observations were used to generate each model. Base temperature, the temperature at which plant development stops, was calculated under 5 and $15 \mathrm{~mol} \cdot \mathrm{m}^{-2} \cdot \mathrm{d}^{-1}$ by inputting the DLI into the rate of progress to flower equation and setting the equation equal to zero. The DLIs of 5 and $15 \mathrm{~mol} \cdot \mathrm{m}^{-2} \cdot \mathrm{d}^{-1}$ were arbitrarily chosen to represent typical DLIs in commercial greenhouses when most bedding plants are produced.

\section{Results}

Celosia. Rate of progress to flowering was quadratically related with temperature and DLI (Table 1). Within the range of observed DLI, rate of progress to flowering increased as temperature increased up to $\approx 25^{\circ} \mathrm{C}$ (Fig. 1A). An increase in the average DLI from 5 to $15 \mathrm{~mol} \cdot \mathrm{m}^{-2} \cdot \mathrm{d}^{-1}$ accelerated the rate of progress to flowering, especially for plants grown at the lowest air temperatures $\left(15\right.$ to $20^{\circ} \mathrm{C}$ ), but a further increase in DLI had little or no effect on flowering rate. The calculated base temperature for plants grown under an average DLI of 5 or $15 \mathrm{~mol} \cdot \mathrm{m}^{-2} \cdot \mathrm{d}^{-1}$ was 11.7 or $10.2^{\circ} \mathrm{C}$, respectively.

Number of nodes at flowering was highly variable in the temperature and DLI treatments provided (data not shown). The model used to fit the data had a low coefficient of determination $\left(r^{2}=0.20\right.$; Table 1$)$. The actual number of nodes varied from 13 to 35 , although $73 \%$ of plants developed between 17 and 23 nodes before flowering.

Temperature and DLI interacted to influence plant height and flower number. DLI had little effect on plant height at flowering when the air temperature was low (e.g., $\left.15^{\circ} \mathrm{C}\right)$. Height increased as the average temperature and DLI increased (Fig. 1B). For example, as temperature increased from 15 to $28^{\circ} \mathrm{C}$, plant height increased from 17 to $27 \mathrm{~cm}$ under an average DLI of $8 \mathrm{~mol} \cdot \mathrm{m}^{-2} \cdot \mathrm{d}^{-1}$, and from 17 to $22 \mathrm{~cm}$ under $24 \mathrm{~mol} \cdot \mathrm{m}^{-2} \cdot \mathrm{d}^{-1}$. Flower number at first open flower decreased as DLI decreased, but the magnitude depended on temperature (Fig. 1C). Under $25 \mathrm{~mol} \cdot \mathrm{m}^{-2} \cdot \mathrm{d}^{-1}$, flower number was greatest (22) at $22{ }^{\circ} \mathrm{C}$ and slightly decreased as temperature increased or decreased. Under $5 \mathrm{~mol} \cdot \mathrm{m}^{-2} \cdot \mathrm{d}^{-1}$, flower number was maximal (16) at $16^{\circ} \mathrm{C}$ and decreased to 7 as temperature increased to $28^{\circ} \mathrm{C}$. Flower size was not recorded for celosia, because the length of the inflorescence was the characteristic used to define when plants were in flower.

Plant shoot dry mass at first flowering increased as the average temperature and DLI increased (Fig. 1D). For example, at $14^{\circ} \mathrm{C}$, plants under $5 \mathrm{~mol} \cdot \mathrm{m}^{-2} \cdot \mathrm{d}^{-1}$ averaged $1.9 \mathrm{~g}$, whereas those under $25 \mathrm{~mol} \cdot \mathrm{m}^{-2} \cdot \mathrm{d}^{-1}$ averaged $5.5 \mathrm{~g}$. For celosia plants grown at an air temperature of $25^{\circ} \mathrm{C}$, plant dry mass doubled (from 3.6 to $7.2 \mathrm{~g}$ ) when the DLI increased from 5 to $25 \mathrm{~mol} \cdot \mathrm{m}^{-2} \cdot \mathrm{d}^{-1}$. 
Table 1. Parameters of regression analysis relating rate of progress to flowering (1/days to flower), plant height, shoot dry mass, and node and flower number for celosia and impatiens to average air temperature $\left[\mathrm{T}\left({ }^{\circ} \mathrm{C}\right)\right]$ and daily light integral $\left[\mathrm{DLI}\left(\mathrm{mol} \cdot \mathrm{m}^{-2} \cdot \mathrm{d}^{-1}\right)\right]$.

\begin{tabular}{|c|c|c|c|c|c|c|c|}
\hline Parameter & Intercept & $\mathrm{T}$ & $\mathrm{T}^{2}$ & DLI & $\mathrm{DLI}^{2}$ & $\mathrm{~T} * \mathrm{DLI}$ & $r^{2}$ \\
\hline \multicolumn{8}{|c|}{ Celosia argentea var. plumosa 'Gloria Mix' } \\
\hline $1 /$ days to flower & $\begin{array}{l}-7.23 \mathrm{E}-2^{\mathrm{z}} \\
(8.37 \mathrm{E}-3)^{\mathrm{y}}\end{array}$ & $\begin{array}{c}7.40 \text { E-3 } \\
(7.92 \text { E-4) }\end{array}$ & $\begin{array}{c}-1.45 \mathrm{E}-4 \\
(1.86 \mathrm{E}-5)\end{array}$ & $\begin{array}{c}1.26 \mathrm{E}-3 \\
\pm(2.18 \mathrm{E}-4)\end{array}$ & $\begin{array}{l}-3.12 \text { E-5 } \\
(6.63 \text { E-6) }\end{array}$ & $-1 x$ & 0.67 \\
\hline Height $(\mathrm{cm})$ & $\begin{array}{c}4.59 \\
(1.43)\end{array}$ & $\begin{array}{c}0.97 \\
(0.10)\end{array}$ & - & - & $\begin{array}{c}1.00 \mathrm{E}-2 \\
(3.49 \mathrm{E}-3)\end{array}$ & $\begin{array}{c}-2.30 \mathrm{E}-2 \\
(5.19 \mathrm{E}-3)\end{array}$ & 0.43 \\
\hline Dry mass (g) & $\begin{array}{c}1.00 \\
(0.24)\end{array}$ & - & $\begin{array}{c}3.94 \mathrm{E}-3 \\
(4.33 \mathrm{E}-4)\end{array}$ & - & $\begin{array}{c}5.90 \mathrm{E}-3 \\
(3.77 \mathrm{E}-4)\end{array}$ & - & 0.53 \\
\hline Node no. & $\begin{array}{l}31.01 \\
(6.67)\end{array}$ & $\begin{array}{l}-1.28 \\
(0.63)\end{array}$ & $\begin{array}{c}3.70 \mathrm{E}-2 \\
(1.50 \mathrm{E}-2)\end{array}$ & $\begin{array}{l}-3.29 \mathrm{E}-1 \\
(1.67 \mathrm{E}-1)\end{array}$ & $\begin{array}{c}1.50 \mathrm{E}-2 \\
(5.28 \mathrm{E}-3)\end{array}$ & - & 0.20 \\
\hline Flower no. & $\begin{array}{c}3.01 \\
(7.01)\end{array}$ & $\begin{array}{l}1.66 \\
(0.65)\end{array}$ & $\begin{array}{l}-5.90 \mathrm{E}-2 \\
(1.50 \mathrm{E}-2)\end{array}$ & $\begin{array}{l}-4.49 \mathrm{E}-1 \\
(1.61 \mathrm{E}-1)\end{array}$ & - & $\begin{array}{c}4.10 \mathrm{E}-2 \\
(7.58 \mathrm{E}-3)\end{array}$ & 0.46 \\
\hline \multicolumn{8}{|c|}{ Impatiens wallerana 'Accent Red' } \\
\hline $1 /$ days to flower & $\begin{array}{l}-4.80 \mathrm{E}-2 \\
(1.48 \mathrm{E}-2)\end{array}$ & $\begin{array}{c}5.70 \mathrm{E}-3 \\
(1.40 \mathrm{E}-3)\end{array}$ & $\begin{array}{l}-7.98 \mathrm{E}-5 \\
(3.35 \mathrm{E}-5)\end{array}$ & $\begin{array}{c}2.14 \text { E-3 } \\
(4.89 \text { E-4) }\end{array}$ & $\begin{array}{l}-3.29 \mathrm{E}-5 \\
(1.11 \mathrm{E}-5)\end{array}$ & $\begin{array}{l}-6.48 \mathrm{E}-5 \\
(1.62 \mathrm{E}-5)\end{array}$ & 0.41 \\
\hline Height $(\mathrm{cm})$ & $\begin{array}{l}-4.26 \\
(3.58)\end{array}$ & $\begin{array}{c}1.21 \\
(0.35)\end{array}$ & $\begin{array}{l}-2.70 \mathrm{E}-2 \\
(8.37 \mathrm{E}-3)\end{array}$ & - & $\begin{array}{c}4.18 \mathrm{E}-3 \\
(5.45 \mathrm{E}-4)\end{array}$ & - & 0.21 \\
\hline Dry mass (g) & $\begin{array}{c}1.47 \\
(0.20)\end{array}$ & - & $\begin{array}{l}-1.49 \mathrm{E}-3 \\
(3.73 \mathrm{E}-4)\end{array}$ & - & $\begin{array}{l}4.12 \mathrm{E}-3 \\
(3.19 \mathrm{E}-4)\end{array}$ & - & 0.38 \\
\hline Flower no. & $\begin{array}{l}92.90 \\
(4.90)\end{array}$ & - & $\begin{array}{l}-1.13 \mathrm{E}-1 \\
(8.92 \mathrm{E}-3)\end{array}$ & - & $\begin{array}{c}9.81 \mathrm{E}-2 \\
(7.78 \mathrm{E}-3)\end{array}$ & - & 0.53 \\
\hline Flower diam $(\mathrm{cm})$ & $\begin{array}{c}3.88 \\
(0.65)\end{array}$ & $\begin{array}{c}0.16 \\
(0.06)\end{array}$ & $\begin{array}{l}-6.27 \text { E-3 } \\
(1.50 \text { E-3) }\end{array}$ & $\begin{array}{c}6.50 \mathrm{E}-2 \\
(1.60 \mathrm{E}-2)\end{array}$ & $\begin{array}{l}-1.90 \text { E-3 } \\
(4.98 \text { E-4) }\end{array}$ & - & 0.62 \\
\hline
\end{tabular}

${ }^{\mathrm{z}}$ Coefficients for model equations were used to generate Figs. 1 and 2.

${ }^{\mathrm{y}}$ Standard error.

${ }^{\mathrm{x}}$ Parameter is nonsignificant at $P \geq 0.05$ or value is $<0.0001$.
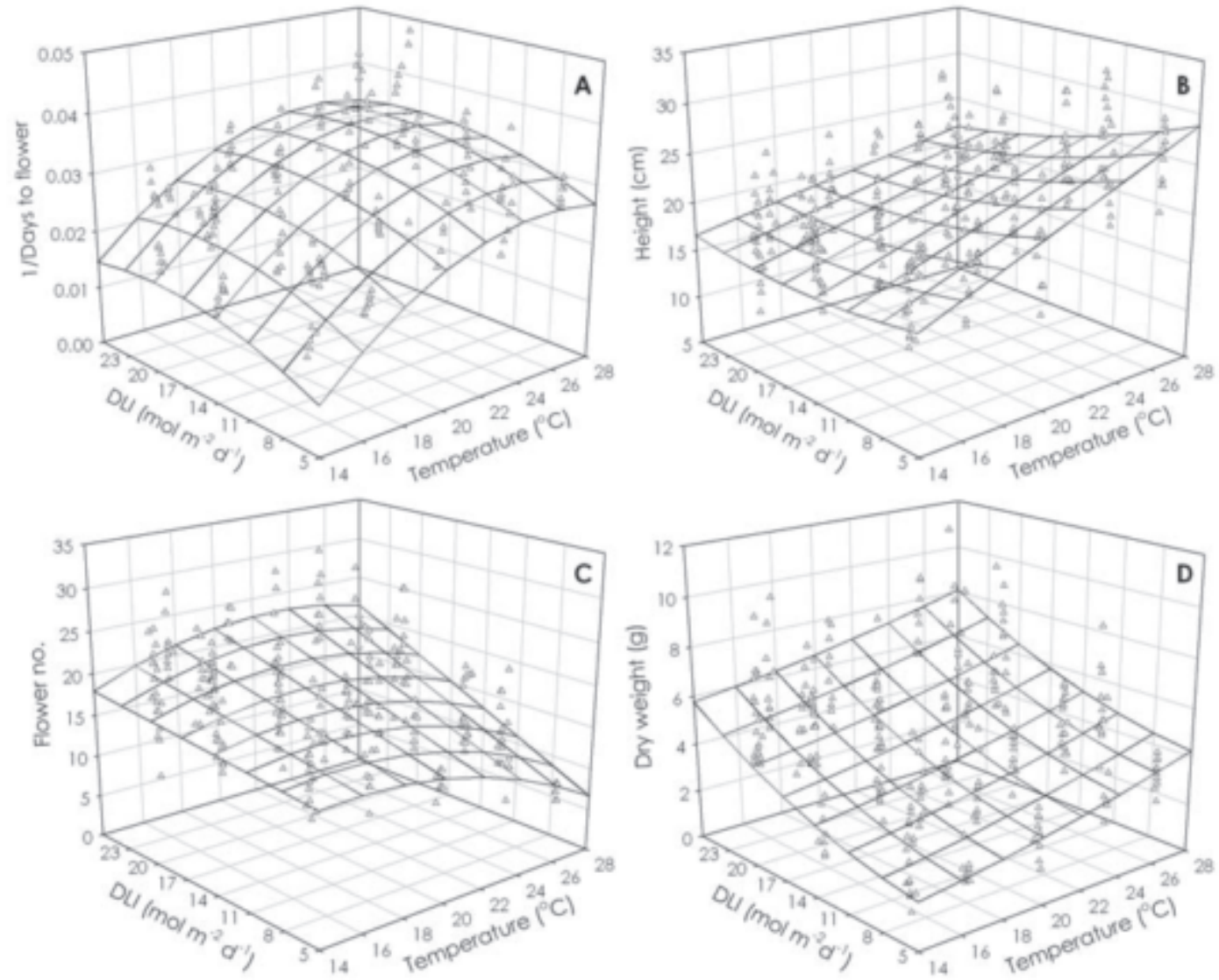

Fig. 1. Temperature and daily light integral (DLI) effects on celosia (A) rate of progress toward flowering (1/days to flower) and (B) plant height, (C) flower bud number, and (D) shoot dry mass at flowering. The coefficients for the models are presented in Table 1. 
IMPATIENS. Temperature and DLI interacted to influence rate of progress toward flowering (Table 1). Plants grown under a low DLI $\left(<15 \mathrm{~mol} \cdot \mathrm{m}^{-2} \cdot \mathrm{d}^{-1}\right)$ flowered progressively earlier as temperature increased from 14 to $28^{\circ} \mathrm{C}$ (Fig. 2A). Under a higher DLI, there was less effect of temperature on time to flowering, and plants grown at the highest DLI and temperature treatments flowered nonuniformly. The calculated plant base temperature grown under an average DLI of 5 or $15 \mathrm{~mol} \cdot \mathrm{m}^{-2} \cdot \mathrm{d}^{-1}$ was 7.5 or $4.3{ }^{\circ} \mathrm{C}$, respectively. Some plants flowered first on the primary shoot, and other plants flowered first on an axillary shoot (data not shown). Therefore, number of nodes was highly variable and is not presented.

Plant height at flowering increased as DLI increased, regardless of the air temperature (Table 1). Plants were shortest $(7.5 \mathrm{~cm})$ when grown under low DLI and temperature, and height increased as the air temperature increased to $22^{\circ} \mathrm{C}$ to a maximum of 11.9 $\mathrm{cm}$ (data not shown). Temperature had little or no effect on plant height above $22{ }^{\circ} \mathrm{C}$. However, the coefficient of determination for the model was relatively low $\left(r^{2}=0.21\right)$ partly because of the high variability in plants grown at the highest temperature and especially highest DLI treatments.
Flower diameter decreased as temperature increased from 15 to $28^{\circ} \mathrm{C}$, and the effects of DLI were relatively small (Fig. 2B). Regardless of DLI, impatiens flower diameter predicted by the model is $\geq 5.2 \mathrm{~cm}$ for plants grown at $15^{\circ} \mathrm{C}$ and $\leq 4.0 \mathrm{~cm}$ for plants grown at $28^{\circ} \mathrm{C}$ (Table 1). Flower number increased as the actual average daily temperature decreased or DLI increased (Fig. 2C). For example, at $14^{\circ} \mathrm{C}$, flower number increased by $88 \%$ as DLI increased from 5 to $25 \mathrm{~mol} \cdot \mathrm{m}^{-2} \cdot \mathrm{d}^{-1}$, and at $26^{\circ} \mathrm{C}$ flower number increased by $330 \%$. Shoot dry mass at flowering increased as DLI increased at all temperatures delivered in the experiments (Fig. 2D). For example, at $20^{\circ} \mathrm{C}$, dry mass was $72 \%$ lower under a DLI of $5 \mathrm{~mol} \cdot \mathrm{m}^{-2} \cdot \mathrm{d}^{-1}$ compared to $25 \mathrm{~mol} \cdot \mathrm{m}^{-2} \cdot \mathrm{d}^{-1}$.

\section{Discussion}

Time to flowering was significantly influenced by temperature and DLI in both celosia and impatiens. Within the observed temperature and DLI ranges, a maximal rate of development (i.e., greatest rate of progress toward flowering) was observed for celosia at $\approx 25{ }^{\circ} \mathrm{C}$ and impatiens at $\approx 26{ }^{\circ} \mathrm{C}$, above which a further increase in temperature did not accelerate flowering. These
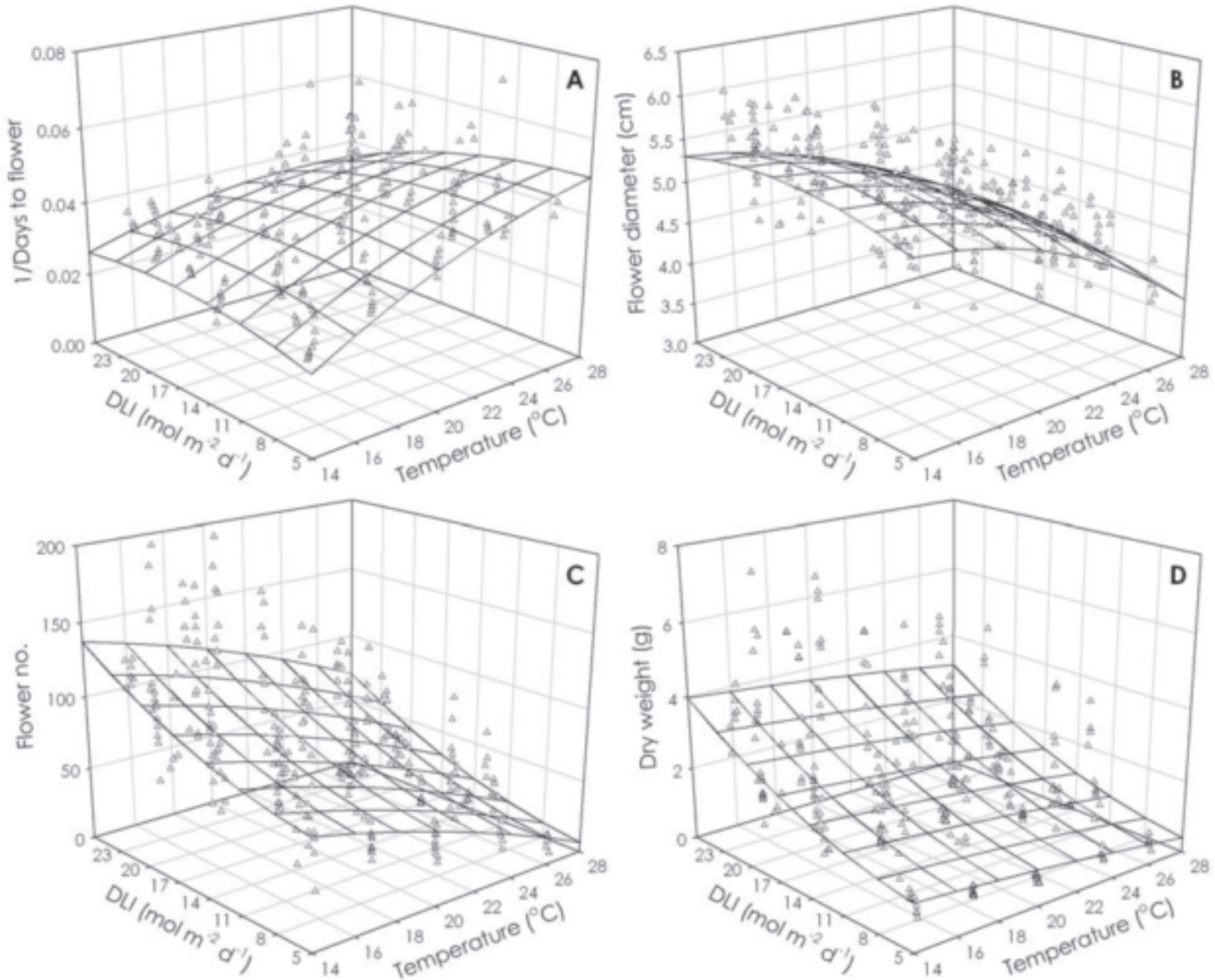

Fig. 2. Temperature and daily light integral (DLI) effects on impatiens (A) rate of progress toward flowering (1/days to flower) and (B) flower diameter, (C) flower bud number, and (D) shoot dry mass at flowering. The coefficients for the models are presented in Table 1. 
temperatures are higher than the maximal temperature for pansy (Viola $\times$ wittrockiana Gams., $22^{\circ} \mathrm{C}$ ) and dahlia (Dahlia pinnata Cav., $24^{\circ} \mathrm{C}$ ), similar to that reported in petunia (Petunia $\times$ hybrida Vilm.-Andr., $25^{\circ} \mathrm{C}$ ) and lower than that for vinca (Catharanthus roseus L., $35^{\circ} \mathrm{C}$ ) (Adams et al., 1997; Brøndum and Heins, 1993; Kaczperski et al., 1991; Pietsch et al., 1995).

The base temperature of a plant is usually estimated as the air temperature at which the rate of plant development is zero. We included the DLI parameter in our base temperature calculations because light is a form of energy that can influence plant temperature. For example, a poinsettia (Euphorbia pulcherrima Willd. ex Klotzsch) model predicted that shoot-tip temperature increases linearly by $0.67{ }^{\circ} \mathrm{C}$ for every $100 \mathrm{~W} \cdot \mathrm{m}^{-2}$ increase in radiation, holding other environmental parameters constant (Shimizu et al., 2004). In vinca, the calculated base temperature was $10^{\circ} \mathrm{C}$ when plants were grown in a greenhouse with $50 \%$ shadecloth and 12 ${ }^{\circ} \mathrm{C}$ without shadecloth (Pietsch et al., 1995).

Our estimates of base temperature are based on the effect of air temperature and DLI on plant temperature. The estimated base temperature for celosia decreased by $1.5^{\circ} \mathrm{C}$ (from 11.7 to $10.2^{\circ} \mathrm{C}$ ) as DLI increased from 5 to $15 \mathrm{~mol} \cdot \mathrm{m}^{-2} \cdot \mathrm{d}^{-1}$, which suggests that average plant temperature at $11.7^{\circ} \mathrm{C}$ under a DLI of $5 \mathrm{~mol} \cdot \mathrm{m}^{-2} \cdot \mathrm{d}^{-1}$ would be equal to average plant temperature at $10.2{ }^{\circ} \mathrm{C}$ under a DLI of $15 \mathrm{~mol} \cdot \mathrm{m}^{-2} \cdot \mathrm{d}^{-1}$. Similar responses were observed for impatiens, in which the calculated base temperature was 7.5 or $4.3^{\circ} \mathrm{C}$ with a DLI of 5 or $15 \mathrm{~mol} \cdot \mathrm{m}^{-2} \cdot \mathrm{d}^{-1}$, respectively. The base temperature has been calculated without considering DLI for other garden plant crops, including coreopsis (Coreopsis grandiflora Hogg ex Sweet., $\left.6.8^{\circ} \mathrm{C}\right)$, dahlia $\left(5.5^{\circ} \mathrm{C}\right.$ for leaf unfolding), and gaillardia (Gaillardia $\times$ grandiflora Van Houtte, $3.3^{\circ} \mathrm{C}$ ) (Brøndum and Heins, 1993; Yuan et al., 1998).

A high DLI can accelerate flowering by reducing node number before development of the first flower. Plants that develop fewer nodes before flower initiation from an increase in DLI have been described as having a facultative irradiance response (Erwin et al., 2004). In addition, a high DLI can accelerate flowering by increasing plant temperature. For example, studies with vinca showed that plants receiving supplemental light from HPS lamps at 50,75 , and $100 \mu \mathrm{mol} \cdot \mathrm{m}^{-2} \cdot \mathrm{s}^{-1}$ were $1.2,1.5$, and $1.7^{\circ} \mathrm{C}$ warmer, respectively, than plants in darkness (Faust and Heins, 1997). Here, number of nodes at flowering was highly variable for celosia and especially impatiens, and there were no definitive trends between DLI and node number. Therefore, the increase in celosia flowering rate as DLI increased to $15 \mathrm{~mol} \cdot \mathrm{m}^{-2} \cdot \mathrm{d}^{-1}$ can be primarily attributed to an increase in plant temperature. In impatiens, the effect of DLI varied with temperature, and at $>20^{\circ} \mathrm{C}$ the model predicted a delay in flowering when the average DLI was $>15 \mathrm{~mol} \cdot \mathrm{m}^{-2} \cdot \mathrm{d}^{-1}$. Impatiens tolerates deep shade, and plants grown with a high DLI and at a high temperature could have reduced growth and delayed flowering (Dole and Wilkins, 2005).

The models developed to predict flowering time and plant quality characteristics (e.g., flower number) varied in goodness of fit. For example, the model represented in Fig. 1A predicted time to flower of celosia within $\pm 5 \mathrm{~d}$ for $68 \%$ of the actual data (Fig. 3). Similarly, the impatiens model generated in Fig. 2A predicted days to flower within $\pm 5 \mathrm{~d}$ for $70 \%$ of the actual data (Fig. 3). Similar models developed for salvia (Salvia splendens F. Sello ex Roem \& Schult.) and marigold (Tagetes patula L.) predicted actual flowering time within $5 \mathrm{~d}$ for $>90 \%$ of the data (Pramuk, 2003). Some of the flowering variability with celosia and impatiens could be explained by genetic variability within the seed populations. Additionally, celosia 'Gloria Mix' is a

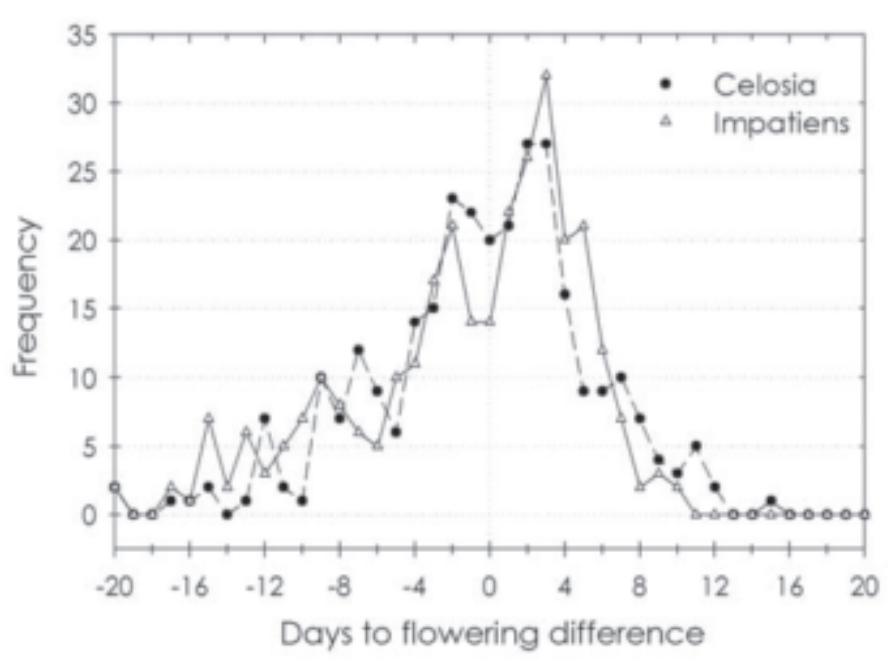

Fig. 3. Frequency of predicted minus actual days to flower in celosia and impatiens grown at different temperatures $\left(\approx 15\right.$ to $\left.27^{\circ} \mathrm{C}\right)$ and daily light integrals $(\approx 7$ to $\left.26 \mathrm{~mol} \cdot \mathrm{m}^{-2} \cdot \mathrm{d}^{-1}\right)$. The models used to predict flowering time are shown in Table 1 and are based on 296 and 298 observations for celosia and impatiens, respectively.

multicolored cultivar, which may have more genetic variability than a single-colored cultivar.

Rapid flowering is of primary interest to greenhouse growers so that production time can be minimized. However, there is often a tradeoff between rapid flowering and high plant quality. Plantquality characteristics for bedding plants include stem thickness and branching (which can be associated with shoot dry mass at flowering), flower bud number, and flower size. In campanula (Campanula carpatica Jacq. 'Blue Clips'), plant shoot dry mass decreased linearly as the average daily temperature decreased from 25 to $15^{\circ} \mathrm{C}$ when the average DLI was 10.8 or $15.8 \mathrm{~mol} \cdot \mathrm{m}^{-2} \cdot \mathrm{d}^{-1}$ (Niu et al., 2001). In addition, dry mass of campanula increased by $155 \%$ when DLI increased from 4.2 to $10.8 \mathrm{~mol} \cdot \mathrm{m}^{-2} \cdot \mathrm{d}^{-1}$ and by $25 \%$ when DLI increased from 10.8 to $15.8 \mathrm{~mol} \cdot \mathrm{m}^{-2} \cdot \mathrm{d}^{-1}(\mathrm{Niu}$ et al., 2001). In yarrow (Achillea millefolium L.), gaura (Gaura lindheimeri Engelm. \& Gray), and lavender (Lavandula angustifolia Mill.), quality ratings (which included stem thickness, flower color, and branching) increased as the DLI increased from 5 to 20 $\mathrm{mol} \cdot \mathrm{m}^{-2} \cdot \mathrm{d}^{-1}$ (Fausey et al., 2005). In our experiments, dry mass at flowering increased as DLI increased from 5 to $25 \mathrm{~mol} \cdot \mathrm{m}^{-2} \cdot \mathrm{d}^{-1}$ in both species, and in impatiens, dry mass decreased with increasing temperature. In contrast, celosia dry mass at flowering increased with increasing temperature, despite the more rapid flowering (and thus less time to harvest light) at the highest temperatures. Plants grown at temperatures $<18{ }^{\circ} \mathrm{C}$ were pale green and chlorotic, which suggests a decreased photosynthetic capacity for plants grown at low temperatures. Similar observations have been reported by Hamrick (2003).

Flower number at first flowering decreased as temperature increased, except for celosia grown under a high DLI. Thus, plants had more time to harvest light before flowering when grown at the cooler temperatures, presumably producing more photosynthate for flowers. In previous studies with 'Sunray' coreopsis, rudbeckia (Rudbeckia fulgida Ait. 'Goldsturm'), and Shasta daisy (Leucanthemum $\times$ superbum Bergman ex. J. Ingram 'Snowcap'), flower bud number at time of flowering decreased $80 \%, 75 \%$, and $55 \%$, respectively, as temperature increased from $16{ }^{\circ} \mathrm{C}$ to $26^{\circ} \mathrm{C}$ (Yuan et al., 1998). In campanula, the number 
of flower buds decreased linearly, at 10 flowers per ${ }^{\circ} \mathrm{C}$, as plant temperature increased from 16 to $24{ }^{\circ} \mathrm{C}$ (Niu et al., 2001). In addition, flower number of celosia and impatiens increased as DLI increased at all temperatures studied.

The models developed to predict flowering time and plant quality could be used by commercial growers to determine the impacts of changing growing temperature, growing plants at different times of the year, and providing supplemental lighting. For example, celosia plants grown under an average DLI of $8 \mathrm{~mol} \cdot \mathrm{m}^{-2} \cdot \mathrm{d}^{-1}$ are predicted to flower from transplant in $45 \mathrm{~d}$ at $18{ }^{\circ} \mathrm{C}$ and in $34 \mathrm{~d}$ at $23{ }^{\circ} \mathrm{C}$. Growing plants at these same air temperatures but with a DLI of $16 \mathrm{~mol} \cdot \mathrm{m}^{-2} \cdot \mathrm{d}^{-1}$ would accelerate flowering by 8 and 4 $\mathrm{d}$, respectively. In addition, plant dry mass at first flowering is predicted to increase by $41 \%$ and $31 \%$ when the average DLI increases from 8 to $16 \mathrm{~mol} \cdot \mathrm{m}^{-2} \cdot \mathrm{d}^{-1}$ at 18 and $23{ }^{\circ} \mathrm{C}$, respectively. For impatiens, decreasing the average daily temperature from 23 to $18^{\circ} \mathrm{C}$ would delay flowering from transplant by 6 or $5 \mathrm{~d}$ under an average DLI of 8 or $16 \mathrm{~mol} \cdot \mathrm{m}^{-2} \cdot \mathrm{d}^{-1}$, respectively. The impatiens models predict that increasing the DLI from 8 to 16 $\mathrm{mol} \cdot \mathrm{m}^{-2} \cdot \mathrm{d}^{-1}$ would increase flower bud number by $29 \%$ and $49 \%$ and plant dry mass by $63 \%$ and $84 \%$ at 18 and $23^{\circ} \mathrm{C}$, respectively. This information could be used to improve scheduling accuracy and to predict the consequences of growing plants at different temperatures or under different DLIs.

\section{Literature Cited}

Adams, S.R., S. Pearson, and P. Hadley. 1997. The effects of temperature, photoperiod and light integral on the time to flowering of pansy cv. Universal Violet (Viola $\times$ wittrockiana Gams.). Ann. Bot. 80:107-112.

Brøndum, J.J. and R.D. Heins. 1993. Modeling temperature and photoperiod effects on growth and development of dahlia. J. Amer. Soc. Hort. Sci. 118:36-42.

Carew, J.G., K. Mahood, J. Darby, P. Hadley, and N.H. Battey. 2003. The effect of temperature, photosynthetic photon flux density, and photoperiod on the vegetative growth and flowering of 'Autumn Bliss' raspberry. J. Amer. Soc. Hort. Sci. 128:291-296.

Dole, J. and H. Wilkins. 2005. Floriculture principles and species. 2nd ed. Prentice-Hall, Upper Saddle River, N.J.
Energy Information Administration. 1999. Historical natural gas annual 1930 through 1999. Washington, D.C.

Energy Information Administration. 2001. Natural gas monthly September 2001. Washington, D.C.

Erwin, J., N. Mattson, and R. Warner. 2004. Light effects on annual bedding plants, p. 62-71. In: P. Fisher and E. Runkle (eds.). Lighting up profits: Understanding greenhouse lighting. Meister Media Worldwide, Willoughby, Ohio.

Fausey, B.A., R.D. Heins, and A.C. Cameron. 2005. Daily light integral affects flowering and quality of greenhouse-grown Achillea, Gaura, and Lavandula. HortScience 40:114-118.

Faust, J.E. and R.D. Heins. 1997. Quantifying the influence of highpressure sodium lighting on shoot-tip temperature. Acta Hort. 418:85-91.

Hamrick, D. 2003. Ball redbook. 17th ed., vol. 2. Ball Publishing, Batavia, Ill.

Hanan, J. 1998. Greenhouses: Advanced technology for protected horticulture. CRC Press, Boca Raton, Fla.

Kaczperski, M.P., W.H. Carlson, and M.G. Karlsson. 1991. Growth and development of Petunia $\times$ hybrida as a function of temperature and irradiance. J. Amer. Soc. Hort. Sci. 116:232-237.

Korczynski, P.M., J. Logan, and J.E. Faust. 2002. Mapping monthly distribution of daily light integrals across the contiguous United States. HortTechnology 12:12-16.

Niu, G., R.D. Heins, A.C. Cameron, and W.H. Carlson. 2001. Day and night temperatures, daily light integral, and $\mathrm{CO}_{2}$ enrichment affect growth and flower development of Campanula carpatica 'Blue Clips.' Scientia Hort. 87:93-105.

Pietsch, G.M., W.H. Carlson, R.D. Heins, and J.E. Faust. 1995. The effect of day and night temperature and irradiance on development of Catharanthus roseus (L.) 'Grape Cooler.' J. Amer. Soc. Hort. Sci. 120:877-881.

Pramuk, L.A. 2003. Temperature and daily light integral effects of five bedding plant species. MS Thesis, Dept. of Horticulture, Michigan State Univ., East Lansing.

Shimizu, H., E.S. Runkle, and R.D. Heins. 2004. A steady-state model for prediction of poinsettia plant shoot-tip temperature. J. Amer. Soc. Hort. Sci. 129:303-312.

U.S. Dept. of Agriculture. 2004. Floriculture crops 2003 summary. Natl. Agr. Sta. Serv., Washington, D.C.

Yuan, M., W.H. Carlson, R.D. Heins, and A.C. Cameron. 1998. Effect of forcing temperature on Coreopsis grandiflora, Gaillardia $\times$ grandiflora, Leucanthemum $\times$ superbum, and Rudbeckia fulgida. HortScience 33:663-667. 